\title{
Benthic foraminifera in a human-dominated environment: Long Island Sound
}

\author{
Ellen Thomas $^{1} \&$ Johan C. Varekamp ${ }^{2}$ \\ ${ }^{1}$ Department of Geology \& Geophysics, Yale University, New Haven, CT 06520-8109, U.S.A. \\ ellen.thomas@yale.edu \\ ${ }^{2}$ Department of E \& ES, Wesleyan University, Middletown, CT 06459, U.S.A. \\ jvarekamp@wesleyan.edu
}

Long Island Sound (LIS) is a marginally marine urban estuary, with Long Island (NY) as its southern coastline, New York and Connecticut along its northern coast. LIS has a narrow opening to the West (East River), but most exchange with the ocean occurs at its eastern end, resulting in an east-west gradient in salinity. There is also an east-west gradient in indicators of contamination in the surface sediments (e.g., trace metals). Western LIS is close to the main population center (New York City), but also is a focusing region for fine-grained sediments. Since the 1970s, western LIS and to a lesser extent, central LIS, suffer summer hypoxia or even anoxia. We used sediment cores in westernmost and central LIS to document environmental changes over the last millennium, including the time of European settlement, using microfossil, geochemical, sedimentological, and trace element proxies. Sediment ages were determined using metal pollution records and radiometric carbon dating. In the marginal marine environment of LIS, benthic foraminiferal faunas are low-diversity, with slightly higher diversity towards its eastern end. Before European settlement, the assemblages were dominated by Elphidium excavatum (feeding on living diatoms) at shallow depths, where the light penetrates to the bottom (10-15 m). At greater depths, faunas in westernmost LIS were dominated by Elphidium incertum and/or Buccella frigida, by Buccella frigida and/or Eggerella advena over most of LIS. In almost all cores, the absolute abundance of benthic foraminifera and the relative abundance of $E$. excavatum increased from the early-mid 1800s on. In addition, E. excavatum became common at greater depths, where older faunas had been dominated by the agglutinant $E$. advena. The faunal changes coincided with an increase in contaminant trace metal concentration, with human population growth in the region, with a marked decrease in salinity in westernmost LIS, and with the beginning of low oxygen conditions as indicated by carbon isotope values in foraminiferal tests. Accumulation rates of organic carbon and nitrogen 
increased several fold, especially in westernmost LIS. These data suggest that the benthic foraminiferal faunal changes were probably caused by eutrophication, increasing the diatom supply to E. excavatum. Assemblages showed additional, major changes in westernmost LIS beginning in the late 1960s. Foraminiferal abundance decreased, but Ammonia parkinsoniana, formerly absent or rare, became common to dominant, possibly because diatom abundance began to decline at high N/Si values. Decreased dominance of primary producers by diatoms then affected organisms that feed on them (including E. excavatum) and reverberated through the whole ecosystem. 